\title{
How Does a Relative Economy Affect Voter Turnout?
}

\author{
Brandon Beomseob Park ${ }^{1}$ (D)
}

Accepted: 2 July 2021

(c) The Author(s) 2021

\begin{abstract}
Existing studies offer conflicting analyses of the effect of the economy on voter turnout; some studies suggest that a poor economy leads to lower turnout while other studies find the opposite, or no significant effects. One reason for this ambiguity might be rooted in a limited understanding of how voters form attitudes about economic performance. Previous research implicitly presumes that voters' economic assessments are based solely on information about the retrospective domestic economy. In contrast, this study suggests that voters compare their nation's economy with the economies of other nations. If the economy has an effect on turnout, the relative economy will affect voters' evaluations, and consequently their decision to turn out. Employing 'relative economy' variables measured by media-identified spatial reference points across elections and countries from 29 democracies since the 1980s, this paper finds that a poor relative economy leads to lower turnout, while a good relative economy appears to have no effect. The finding has significant implications for the electoral effect of turnout, and thus on democratic accountability.
\end{abstract}

Keywords Retrospective vs. relative economy $\cdot$ Spatial benchmark $\cdot$ Voter turnout

How do macroeconomic conditions affect voter turnout? According to a 'resourcebased' view, increases in economic hardships actually reduce the level of surplus resources available to people, which eventually lead them to spend their limited resources on basic human needs rather than on political participation (the withdrawal hypothesis) (Rosenstone, 1982; Southwell, 1988). Conversely, an abundance of resources leads to higher levels of turnout (Smets \& Van Ham, 2003; Lipset, 1960). Another strand of literature suggests the opposite. An adverse economy creates feelings of dissatisfaction with important aspects of life (Klandermans et al., 2001, p. 42) such as income and employment (Kern et al., 2015), and thus stimulates

Brandon Beomseob Park

beomseob.park@ reading.ac.uk

1 Department of Politics and International Relations, University of Reading, 291 Edith Morley, Reading RG6 6EL, UK 
citizens to voice their grievance by heading to polling stations on election days (the mobilization hypothesis).

In studies of turnout in more advanced economies, however, the question has often been approached from a different perspective, with scholars analyzing voter turnout with a 'competence-based' view. Here, the decision to vote depends upon whether or not a voter believes the government to be competent in handling the economy. For instance, scholars cite rising political distrust and falling levels of political efficacy and democratic satisfaction as evidence of the impact of macroeconomic conditions on voter turnout. This 'competence-based' analysis results in two opposing implications. In the first, economic hardships lead citizens to become frustrated with, indifferent to, and alienated from politics (Taylor, 2000). A negative economy signals to the public that the government is not capable of addressing such problems, which leads to a loss of confidence in representative institutions (Van Erkel \& Van der Meer, 2016) and a loss of enthusiasm in political participation (Taylor, 2000). The alternative implication of the competence-based analysis suggests that citizens under economic hardships are more prone to vote in order to seek redress for their discontent with the government's economic incompetency (Schlozman \& Verba, 1979; Kern et al., 2015). One immediate way to express their discontent is to punish the incumbent government for its economic mismanagement by supporting opposition parties at the polls.

Albeit compelling, the 'resource' and 'competence' based theories of economic impact on voter turnout are not supported by evidence from most cross-national studies, which find no effects of economic fluctuations on voter turnout across regional samples including the US (Arcelus \& Meltzer, 1975), Latin America (Fornos et al., 2004), post-Communist countries (Fauvelle-Aymar \& Stegmaier, 2008), and global samples in Blais and Dobrzynska (1998) and Blais (2000). In fact, both conflicting and null findings lead Blais (2006), in his comprehensive survey of the turnout literature, to conclude that "there is no clear relationship between the economic conjuncture and turnout." (117)

Radcliff (1992) points out that "In part, the confusion may result from measurement and methodological shortcomings." (444) Palmer and Whitten (1999) provide a first insight on the measurement of the economy when observing that voters "primarily concerned with unexpected growth and inflation since unexpected economic changes have real income effects and serve as more reliable indicators of government competence." (Palmer \& Whitten, 1999), p. 625) Building on this line of research, and in response to Radcliff's observation, this paper raises the question of whether economy variables are being properly introduced in the turnout models. Existing studies have predominantly employed temporally measured economy variables such as changes between different years in the level of Gross Domestic Product (GDP), unemployment, and inflation. Retrospective economy measures are appropriate when it comes to testing 'resource-based' hypotheses because they reflect fluctuations in income and material resources.

With regard to 'competence-based' accounts, the use of temporally measured economy variables, albeit useful, entails limitations for predicting how voters form opinions about incumbent performance. This is because citizens extract competence signals not only from the retrospective economy, but also, and more importantly, 
from the relative economy. In other words, people tend to base their assessment of their government's competence on comparisons between the state of their economy and that of other countries. Indeed, recent scholarship has investigated an 'acrossnations' yardstick as an alternative source of competence signal (Kayser \& Peress, 2012; Aytaç, 2018; Park, 2019). The spatially-benchmarked economy (or the relative economy) has been found to affect citizens' electoral behavior significantly and does so more than the temporally measured economy (Kayser \& Peress, 2012; Park, 2019). Thus, the previous approach of employing retrospective economy variables cannot fully explain how voters arrive at economic evaluations, and as a result, will suggest an insufficient depiction of the relationship between the economy and voter turnout.

If the relative economy has more of an effect on voter attitudes toward their government than the retrospective economy, we should consider the possibility that the relative economy may better capture the competence signal of the government. In this regard, at least in testing for competence-based accounts, the relative economy variables would perform better in the turnout model with greater validity by measuring what they are purported to measure. To the best of the author's knowledge, no studies have incorporated the idea of relative economy in their voter turnout models, even when operating under competence-based (rather than resource-based) theoretical mechanisms. This paper attempts to fill the gap in the literature by employing the spatially-benchmarked economy to test 'competence-based' accounts over the link between the economy and turnout. The next section demonstrates how voters take into account information about the relative economy and how that information determines whether or not they will turn out to vote.

\section{How Does the Relative Economy Affect Voter Turnout?}

Similar to the Vote-Popularity function, which considers incumbent support to be influenced by the state of the economy, ${ }^{1}$ the underlying mechanism of the link between the economy and turnout, either through mobilization or withdrawal, is based on voter assessments of the incumbent's competence in handling the economy. If voters wish to express their grievance about a poor economy by holding their government accountable at the polls, they must be able to extract the competence signal, which captures the extent to which shocks to the economy are perceived as a result of the competence of government (Duch \& Stevenson, 2008). The same logic applies to the 'withdrawal' hypothesis. If voters become alienated from and indifferent to politics due to a loss of confidence in their government, and therefore become reluctant to participate in elections, they also have to be able to determine the extent to which economic hardships are exacerbated by the incumbent's managerial skill. In other words, competence signals from incumbents are important factors in determining whether or not voters decide to show up at the polls.

\footnotetext{
${ }^{1}$ For a review, see Stegmaier et al. (2017).
} 
However, voters may not be able to extract the competence signal from the observed economy (Duch \& Stevenson, 2008). This is because the observed economy consists of two parts-competency shock and exogenous shock-and voters cannot reliably isolate one from the other. If adverse economic conditions are not driven by incumbent competency but rather by exogenous shocks, such as a global financial crisis or an oil shock, there is less reason to conclude that the poor economy can be blamed on the incumbent's competency. As such, extracting competence signals from the observed economy is an important task for voters should they want to avoid inappropriate assessments of their elected officials. Thus, the first step that voters should take is to evaluate whether the current state of their economy is due more to an exogenous shock or incumbent competency.

Comparisons provide a heuristic shortcut in voters' minds, which helps them extract competence signals from the composite parts of the observed economy (Duch \& Stevenson, 2008). Although ordinary citizens commonly make both temporal and spatial comparisons in their daily lives, scholars have predominantly used the temporal approach for comparisons in their turnout models. Specifically, studies examining the effects of the economy on voter turnout have mostly included economic indicators derived from comparisons between current values and past values. By relying on one-dimensional comparison strategy, scholars unwittingly force voters to evaluate the state of the economy only by looking to the past in their turnout models.

Voters may perceive that the national economy is performing worse this year compared to the average growth from past years. However, that average growth could serve as a poor or incomplete benchmark if these voters also perceive that the economic growth of the current year in their country exceeds that of their neighboring countries. A temporal comparison, in this regard, is limited in its ability to help voters distinguish competency shock from exogenous shock, and therefore provides insufficient information about incumbent competency.

Spatial comparison therefore provides voters with useful information. For instance, if voters in Country A realize that their economy is declining in tandem with the economy of neighboring Country B (or the entire region's economy), the voters in Country A will recognize the possibility of an exogenous shock rather than a competence shock. The decline in Country A's economy would not be perceived as managerial incompetence when all other neighboring countries have undergone similar economic adversity. By contrast, if the decline in growth rate is only observed in Country A while either no change in growth or even a positive growth rate appears in benchmarked Country B, it becomes apparent for voters in Country A that their economy's poor performance is a sign of the managerial incompetence of their government. In sum, once voters extract the competence signal by making spatial comparisons, it is easy for them to make a decision on whether to turn out.

In the remainder of this section, four testable hypotheses are developed. These hypotheses predict variations in aggregate turnout levels based on relatively poor and relatively good economic conditions. Applying the logic of both withdrawal and mobilization theories, plausible arguments can be made for two opposing directions, increasing and decreasing turnout levels. Thus, hypotheses are posited in both directions for variables that are good proxies for relative economic performance. 


\section{Hypotheses}

Weschle (2014) suggests two ways in which poor economic management increases indifference among voters. If a group of voters supports the incumbent government, economic hardships will not necessarily lead them to support the opposition, who may be too far away from them on the political spectrum. However, they will also be reluctant to vote for the incumbent, whose poor economic management signals a lack of competence (Weschle, 2014). These voters are therefore more likely to be indifferent and stay at home on election days (Tillman, 2008; Pacek et al., 2009).

The relative economy also affects voter confidence in the incumbent in particular and in politics in general, which in turn impacts the level of turnout. Distrust in and dissatisfaction with politics are indeed often cited as strong predictors for low turnout (Karp \& Milazzo 2015; Hooghe et al., 2011), and distrust in and dissatisfaction with politics among citizens have been shown to depend largely upon their evaluation of policy performance. More specifically, numerous studies have identified negative relationships between poor economic performance and political trust (Van Erkel \& Van der Meer, 2016) ${ }^{2}$ and democratic satisfaction (Quaranta \& Martini, 2016). Consequently, as people become disillusioned with political institutions, democratic performance, and vote choice, they tend to turn out less in elections (Cox, 2003; Grönlund \& Setälä, 2007). Building on this logic, a poor relative economy is expected to lead to a decrease in the level of turnout, and conversely, a good relative economy would be predicted to lead to a higher turnout.

Hypothesis 1a A poor relative economy will decrease the level of turnout.

Hypothesis 1b A good relative economy will increase the level of turnout.

The alternative framework suggests that voters ought to participate in elections more often when they perceive the economy to be poor (Schlozman \& Verba, 1979; Southwell, 1988). In particular, when voters believe that the relatively underperforming economy can be blamed on incumbent incompetency, they are more likely to appear at polling stations to express their grievances by punishing the government with their vote for the opposition. Such grievance is often based on the relative level of perceived deprivation (Klandermans et al. 2008) caused by the relative decline in the rate of economic progress (Gurr, 1970). Kern et al. (2015) have coined the phrase 'collective relative deprivation' for deprivation that occurs at an aggregate level, and they suggest that the collective assessment of economic adversity can increase levels of political participation (Kern et al., 2015; Kriesi, 2012). In sum, voters who clearly feel relatively deprived by the poor relative economy will want to use elections to signal their grievance. This line of reasoning leads to the opposite expectation in $\mathrm{H} 2 \mathrm{a}$ :

\footnotetext{
${ }^{2}$ For a comprehensive review, see Van der Meer (2018).
} 
Hypothesis 2a A poor relative economy will increase the level of turnout.

The fourth hypothesis runs in the opposite direction. An over-performing economy can cause demobilization because voters assume that the incumbent parties are likely to win the election easily. In particular, economic voting literature suggests that a good economy rewards the incumbent with increasing vote share. For instance, at an aggregate level, "for every percentage point of GDP growth in the election year, the incumbent stands to gain 1.4 percent of the vote" (Wilkin et al., 1997, p. 307). Benton (2005, p. 430) suggests a similar estimate of a 1.7 percent shift in incumbent vote share. The evidence is consistent in individual-level studies. Dassonneville and Lewis-Beck (2019: 105) find that the probability of an incumbent vote increases by about 23 percentage points when the economic evaluation of the voters moves from the extremes of 'worse' to 'better'.

As such, if macroeconomic conditions favor the incumbent in an electoral race where there is less at stake, candidates and parties have less incentive to mobilize voters (Cox 1988). These favorable economic conditions are therefore also likely to dampen voters' interest in politics (Karp \& Banducci, 2008) and decrease turnout (Franklin, 2004; Pacek et al., 2009) and political participation (Karp \& Milazzo, 2015). Pacek et al. (2009) highlight this tendency by pointing to Roller et al.'s (2005) report on a survey from post-communist countries which showed that two third of respondents agreed with the statement that "As long as things are getting on well, I'm not really interested in who is in power." (476) Building on this line of reasoning, we can arrive at the fourth hypothesis:

Hypothesis 2b A good relative economy will decrease the level of turnout.

Overall, the mechanism presented in this study suggests a significant connection between relative macroeconomic conditions and voter motivation to turn out, but it is important to note that testing the above-stated hypotheses were performed at the aggregate level. Following the 'funnel of causality' in which various factors are organized in terms of a sequence of variables at different levels (Wass and Blais 2017), the relative economy is considered as a distant cause and one of many contextual factors rather than an immediate cause such as the cost of voting or civic duty (463). Applying the structural chains of logic, voter confidence and trust in and satisfaction with politics and government are influenced by the relative economy as a contextual-level characteristic. In sum, the relative economy affects certain levels and portions of citizens who gain or lose motivation to turn out, which eventually impacts the aggregate levels of turnout in an election.

\section{Model Specification}

To verify above stated arguments, I adopt Arel-Bundock, Blais and Dassonneville (2021) who introduce an innovative way of testing the effects of relative economy in vote choice models. Although their research focuses on incumbent vote share as 


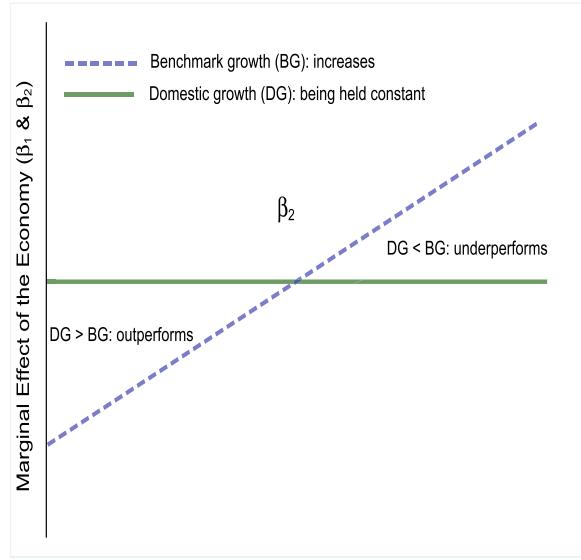

(a) Underperformance

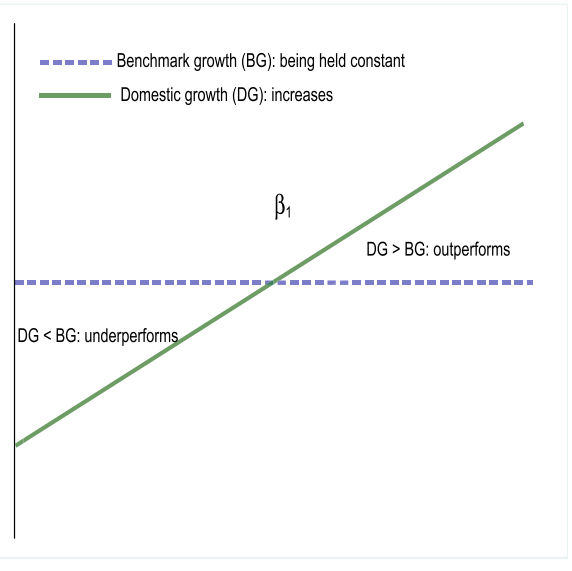

(b) Outperformance

Fig. 1 Marginal Effects of Domestic and Benchmark Growth on Turnout. This is a simple display of Arel-Bundock et al.'s conceputal demonstration (Arel-Bundock et al. 2021, p. 439).

an outcome variable, the empirical strategy that they suggest is not only applicable but also the most appropriate to test the effect of the relative, such as under- or out-performing, economy in turnout models. As the concept of relative economy, by definition, is structured with two economies, domestic and benchmark, Arel-Bundock et al. (2021) present the marginal effects of domestic growth as compared to benchmark growth in Fig. $1 .^{3}$ The solid line indicates the domestic growth rate, and the dashed line shows the growth rate that voters use as a benchmark to evaluate the relative economic conditions.

When the domestic growth is held constant, the benchmark growth increases when we move from left to right in sub-figure (a). This invites a change in relative domestic economic performance from out-performance (i.e., the solid line is above the dashed line) to under-performance (the solid line is below the dashed line), denoted as $\beta_{2}$ in Eq. (1). When this performance gap changes from 'out' to 'under', my H1a predicts that turnout will decreases because voters become more indifferent and alienated from politics as they lose confidence in their government. Conversely, my H2a suggests the opposite: turnout will increase to blame/punish the government for their relative economic strain. In other words, the marginal effect of the benchmark growth should be positive if voters mobilize due to under-performing economy, whereas it should be negative if voters abstain from voting due to lack of confidences in government.

The scenario in sub-figure (b) predicts the opposite. When we move from left to right, the status of relative domestic economy changes from under-performance to out-performance, denoted as $\beta_{1}$ in Eq. (1). Since the domestic economy becomes

\footnotetext{
${ }^{3}$ Note that Arel-Bundock et al. (2021) use incumbent vote share as a dependent variable, whereas I examine voter turnout as the dependent variable.
} 
Table 1 Theoretical expectations of $\operatorname{Beta}(\beta)$ coefficient on turnout

\begin{tabular}{lll}
\hline & $\begin{array}{l}\text { Hypotheses 1 }(a \\
\& b)\end{array}$ & $\begin{array}{l}\text { Hypoth- } \\
\text { eses 2 }(a \\
\& b)\end{array}$ \\
\hline$\beta_{1}$ : Out-performance & $+(b)$ & $-(b)$ \\
$\beta_{2}:$ Under-performance & $-(a)$ & $+(a)$ \\
\hline
\end{tabular}

better than benchmark's, the driving forces of mobilization such as dissatisfaction and grievances are now disappearing, but instead, such out-performance tends to lower the stakes of election by helping the incumbent win re-elections. Thus, turnout will decreases as $\mathrm{H} 2 \mathrm{~b}$ predicts. In contrast, a good relative economy instills a sense of trust and confidence in government, and satisfaction with the politics to the citizens, and consequently increases the portion of voters who are likely to turn out (H1b). As such the marginal effect of the domestic growth will be negative in an election with lower stakes, but it will be positive if the economy-driven confidence lead voters to polling stations.

Based on the intuition, Arel-Bundock et al. (2021) suggest an effective empirical strategy to test the benchmarking theories which has several merits such that it "directly translates the theoretical institutions of benchmarking hypothesis, and immediately reveals the relevant test statistics" (Arel-Bundock et al., 2021, p. 442). In the following model, I modify the dependent variable with Turnout:

$$
\begin{aligned}
& \text { Voter Turnout }_{i t} \\
& \quad=\alpha+\beta_{1} \text { Domestic }_{i t-1}+\beta_{2} \text { Benchmark }_{i t-1}+\beta_{3} \text { Controls }+\varepsilon_{i t}
\end{aligned}
$$

In Eq, (1), the coefficient of Domestic $\left(\beta_{1}\right)$ is the marginal effect of domestic growth on the voter turnout, and the coefficient of Benchmark $\left(\beta_{2}\right)$ measures the marginal effect of the benchmark growth on turnout. ${ }^{4}$ That being said, $\beta_{1}$ represents the marginal effect of domestic growth when the growth of benchmark is held constant, which indicates the out-performing macroeconomic conditions (sub-figure (b) in Fig. 1). The marginal effect of benchmark when the domestic growth is held constant is represented by $\beta_{2}$, directing under-performing macroeconomic conditions (sub-figure (a) in Fig. 1).

Table 1 concisely summarizes the directions of the coefficients based on four distinct hypotheses. The sign of $\beta_{1}$ (a good relative economy) should be positive when voters find strong competence signal in their incumbent $(\mathrm{H} 1 \mathrm{~b})$, whereas it should be negative if the stakes of an election are lower with high probability of incumbents' victory ( $\mathrm{H} 2 \mathrm{~b}$ ). Turning to a poor relative economy, the sign of $\beta_{2}$ should be negative when voters lose their confidence and trust in and satisfaction with their government (H1a), whereas it should be positive if they want to voice their discontents during an election $(\mathrm{H} 2 \mathrm{a})$

\footnotetext{
4 To see, take the partial derivative of Equation (1) with respect to Domestic, then it turns out that the marginal effect of domestic growth is $\beta_{1}$. The partial derivative with respect to Benchmark shows that $\beta_{2}$ is the marginal effect of benchmark growth.
} 


\section{Data and Measures}

To test the hypotheses empirically, I constructed a dataset consisting of 139 of parliamentary and presidential elections in 29 countries since the 1980s. As such, the unit of analysis is the individual election. ${ }^{5}$ The scope of the data restricts itself to the countries and times for which electoral results and media information are available in the ParlGov dataset (Döring \& Manow, 2012). In particular, because I focus on relative economy using the media-coverage-based spatial reference points, explained below, the time dimension of the dataset is heavily restricted to data availability in Lexis-Nexis database.

The outcome variable is Voter Turnout, measured by the percentage of registered voters that go to the polls (Pacek et al., 2009; Powell, 1986; Blais \& Dobrzynska, 1998; Franklin, 2004, Dettrey \& Schwindt-Bayer, 2009) rather than the other one measured as the proportion of the voting-age population that turns out to vote. This is because the latter might cause problems for cross-national comparability due to the exclusion of some groups in voting-age population in some countries (Blais et al., 2001). ${ }^{6}$ I obtain the data of turnout from the Voter Turnout Database of Institute for Democracy and Electoral Assistance (IDEA). ${ }^{7}$

The key explanatory variables are GDP growth rate and unemployment rate. ${ }^{8}$ Since the core arguments of the paper lie in a 'spatially-benchmarked' economy, an immediate question such as "compared to what?" occurs. Social comparison theorists have proposed a general theory of reference points by focusing on various criteria such as familiarity, connectivity, and similarity (Yockey \& Kruml, 2009). Based on this suggestion, Park (2019) attempts to identify unique spatial reference points across countries and elections by looking at the domestic media coverage. More specifically, to examine the distribution of domestic media message on 'foreign' economic performance, Park (2019) collected the volume of news reports on foreign economies from a year prior to an election using Lexis-Nexis, which gives an idea to answer the question of "compared to what" for cross-sectional time-series analyses. ${ }^{9}$

Using Park's (2019) media-identified reference points, I constructed two sets of benchmark. The first spatial reference point, called Benchmark 1, is the one which appears the most in one's own domestic news media on foreign economy. It is also possible that multiple countries, such as X, Y, and Z, jointly appear in the country's domestic news media. To consider these joint reference points, called Benchmark 2,

\footnotetext{
5 The list of elections and years can be found in Online Appendix Table A3.

${ }^{6}$ For a review on turnout measurement, see Online Appendix A in Geys (2006).

7 website: http://www.idea.int

${ }^{8}$ I obtained information on the GDP growth rate from Conference Board (2014), and information of unemployment rate from International Monetary Fund.

9 With regard to using media as the source of finding spatial benchmark(s), Park (2019) highlights two main channels of media, priming and framing, which assist citizens to form relative evaluations. For more discussion, see Park (2019) pp. 3-4.
} 


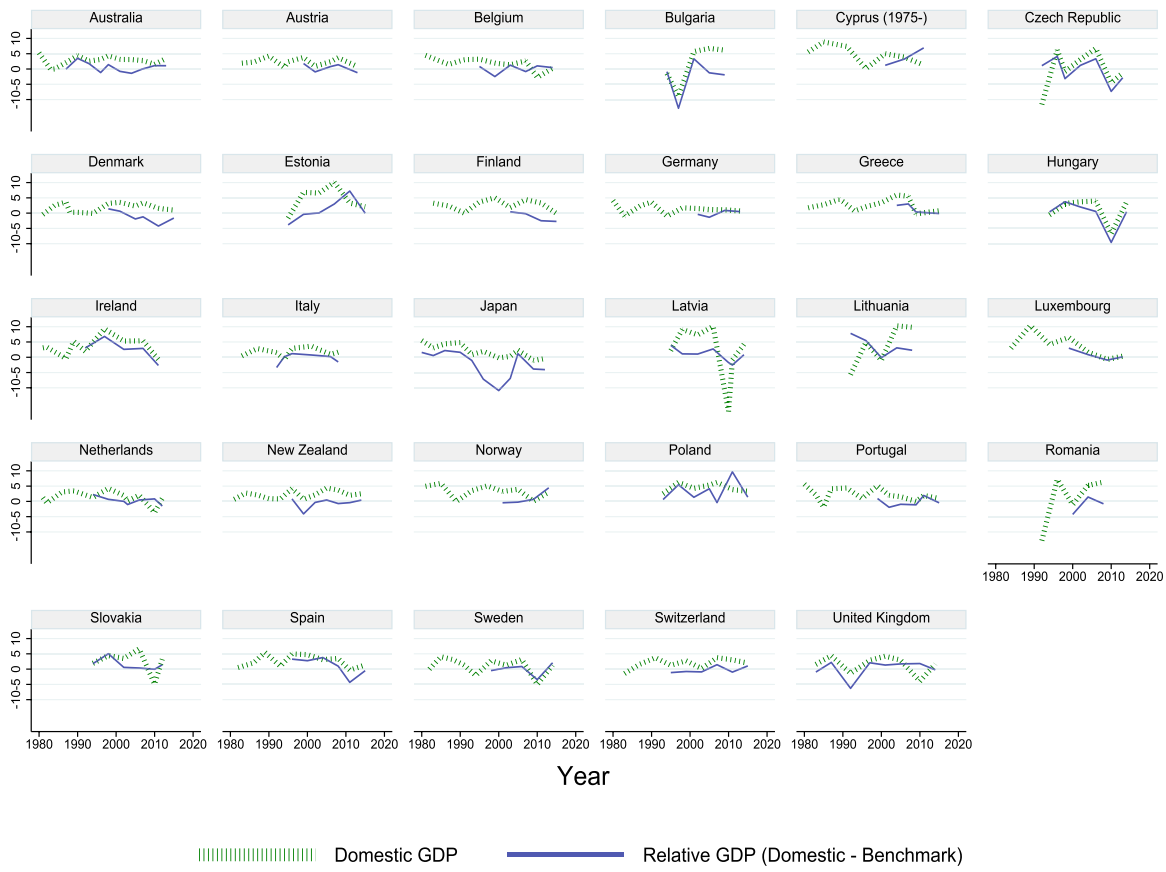

Fig. 2 Variation in domestic and relative GDP across countries

the weighted average of economic indicators from all three countries is used where the weights are given by the proportion of media coverage. ${ }^{10}$

Constructing relative economy based on media-guided spatial benchmark(s) seems not only the appropriate approach, but crucial to ensure empirical accuracy. In particular, in a cross-national time-series analysis, we are likely to employ common reference points such as global average economy if we are uninformed or misinformed about which country(ies) voters tend to benchmark in order to make a comparison. This approach, albeit convenient, is problematic because it assumes that voters across all elections and countries tend to be equally affected by the universal reference points. The relative economy variable, measured based on an inappropriate benchmark, is likely to induce measurement error in the independent variable, and thus, cause that Ordinary Least Square (OLS) estimation leads to an attenuation bias (Pischke, 2007). That being said, employing the key independent variable measured by using the theory-driven and media-guided reference points will reduce a threat of measurement error, and consequently ensure an accurate model-specification.

Figure 2 shows the variations in Domestic GDP (marked with dashed line) and Relative GDP (marked with solid line), using Benchmark 1 as a spatial reference

\footnotetext{
${ }^{10}$ A brief information about the Benchmark is available in the Information about Benchmark(s) section in Online Appendix, and the full information is available in the Supplementary Document of Park (2019) at https://doi.org/10.1016/j.electstud.2019.102085.
} 
point. ${ }^{11}$ The variation in Relative GDP tells us a more detailed story. If the value of Relative GDP is positive, this means domestic GDP outperforms compared to the benchmark GDP. If the Relative GDP line falls below the zero line in the figure, it indicates that the domestic GDP underperforms compared to the benchmark GDP. Indeed, there is great within-country variation in the Relative GDP since the solid line fluctuates across the zero line in most of the countries in Fig. 2. This suggests that most of the countries in the sample do not deliberately benchmark a particular spatial reference point that is a consistently under- or out-performing country.

To account for rival explanations, I include various political and socioeconomic variables based on previous studies. ${ }^{12}$ I include Compulsory Voting variable. ${ }^{13}$ In decades of scholarship, a positive correlation between turnout and mandatory voting has been found (Powell, 1986; Gray \& Caul, 2000; Fornos et al., 2004). The effective number of parties that participate in the election is also controlled. ${ }^{14}$ There are two competing arguments: (1) A larger number of parties increases the choice offered to the voters, enlarging the benefits of voting to the voters (Hansen, 1994); (2) A larger number of parties increases the probability of coalition formation, which can decreases the direct effect of the voters in the choice of government (Blais \& Dobrzynska, 1998). The former expects a positive effect of the number of parties whereas the latter expects the opposite. A dummy variable for presidential election is also included as the data contains both legislative and presidential elections. ${ }^{15}$ In addition, I account for election competitiveness, following the plausible expectation that citizens tend to turn out more in competitive elections because the marginal effect of any additional vote on the outcome is going to be larger the closer the race is (Powell, 1986; Franklin, 2004). It is measured as the absolute value of the percentage point difference in seat share between all governing parties and the opposition at a given election (Franklin, 2004). ${ }^{16}$

Population size and urbanization are also included. Based on Blais (2000), I expect that turnout will be higher in smaller countries because a single vote in a small state is regarded as having a higher probability of being decisive, inviting a larger effect in electoral outcome (Geys, 2006; Blais, 2000). With regard to urbanization, the argument holds that people in cities tend to be more individualistic so that they face less 'peer pressure' to turn out (Riker \& Ordeshook, 1968). ${ }^{17}$ Table A4 in Online Appendix presents the summary statistics of variables.

\footnotetext{
11 One noticeable point is that relative GDP tends to be lower than domestic GDP because, by definition, the relative value is calculated by subtracting the benchmark's value from domestic one. However, when domestic GDP is positive and benchmark economy is negative, the relative GDP becomes greater than the domestic one such as Belgium (2010), Cyprus (2011), Estonia (2008), Latvia (2008, 2010), Poland (2010), the UK (2008), and the Netherlands (2010).

12 In particular, the choice of control variables is guided by Geys (2006) which provides a comprehensive review of aggregate-level research on voter turnout.

13 The information on compulsory voting is based on the IDEA dataset.

14 Bormann and Golder (2013).

15 Information on presidential election comes from Bormann and Golder (2013).

16 I obtained the data on seat shares of parties from Armingeon et al. (2016).

17 I collected data on the size of Population (in 1000's using natural log) and Urbanization from World Bank (2020).
} 
Table 2 Effect of domestic and benchmark economy on voter turnout (PCSE and fixed effects)

\begin{tabular}{|c|c|c|c|c|c|}
\hline \multirow[t]{2}{*}{ DV: Turnout } & \multirow{2}{*}{$\begin{array}{l}\text { Domestic } \\
\text { (1) }\end{array}$} & \multicolumn{2}{|l|}{ Benchmark 1} & \multicolumn{2}{|c|}{ Benchmark 2} \\
\hline & & (2) & (3) & (4) & $(5)$ \\
\hline Previous Turnout & $\begin{array}{l}0.828 * * * \\
(0.062)\end{array}$ & $\begin{array}{l}0.831 * * * \\
(0.062)\end{array}$ & $\begin{array}{l}0.416^{* * * *} \\
(0.141)\end{array}$ & $\begin{array}{l}0.825 * * * \\
(0.059)\end{array}$ & $\begin{array}{l}0.469 * * * \\
(0.135)\end{array}$ \\
\hline Domestic GDP & $\begin{array}{l}-0.048 \\
(0.162)\end{array}$ & $\begin{array}{l}0.281 \\
(0.206)\end{array}$ & $\begin{array}{l}0.268 \\
(0.228)\end{array}$ & $\begin{array}{l}0.234 \\
(0.224)\end{array}$ & $\begin{array}{l}0.141 \\
(0.216)\end{array}$ \\
\hline Domestic Unemployment & $\begin{array}{l}-0.034 \\
(0.146)\end{array}$ & $\begin{array}{l}-0.057 \\
(0.140)\end{array}$ & $\begin{array}{l}0.006 \\
(0.172)\end{array}$ & $\begin{array}{l}-0.026 \\
(0.133)\end{array}$ & $\begin{array}{l}0.042 \\
(0.159)\end{array}$ \\
\hline Benchmark GDP & & $\begin{array}{l}-0.595^{* * *} \\
(0.236)\end{array}$ & $\begin{array}{l}-0.431 * * * \\
(0.201)\end{array}$ & $\begin{array}{l}-0.699 * * * \\
(0.261)\end{array}$ & $\begin{array}{l}-0.411^{* * * *} \\
(0.157)\end{array}$ \\
\hline Benchmark Unemployment & & $\begin{array}{l}-0.143 \\
(0.157)\end{array}$ & $\begin{array}{l}-0.136 \\
(0.218)\end{array}$ & $\begin{array}{l}-0.366^{*} \\
(0.207)\end{array}$ & $\begin{array}{l}-0.410 \\
(0.267)\end{array}$ \\
\hline Effective N. of Party & $\begin{array}{l}-0.351 \\
(0.375)\end{array}$ & $\begin{array}{l}-0.334 \\
(0.325)\end{array}$ & $\begin{array}{l}-0.716 \\
(0.755)\end{array}$ & $\begin{array}{l}-0.343 \\
(0.274)\end{array}$ & $\begin{array}{l}-1.028 \\
(0.701)\end{array}$ \\
\hline Electoral Competition & $\begin{array}{l}-0.035 \\
(0.032)\end{array}$ & $\begin{array}{l}-0.025 \\
(0.029)\end{array}$ & $\begin{array}{l}-0.009 \\
(0.036)\end{array}$ & $\begin{array}{l}-0.024 \\
(0.026)\end{array}$ & $\begin{array}{l}0.001 \\
(0.039)\end{array}$ \\
\hline Presidential Election & $\begin{array}{l}-1.812 \\
(3.195)\end{array}$ & $\begin{array}{l}-1.818 \\
(3.118)\end{array}$ & $\begin{array}{l}1.231 \\
(3.011)\end{array}$ & $\begin{array}{l}-1.581 \\
(3.063)\end{array}$ & $\begin{array}{l}2.103 \\
(2.916)\end{array}$ \\
\hline Population & $\begin{array}{l}-0.306 \\
(0.280)\end{array}$ & $\begin{array}{l}-0.276 \\
(0.307)\end{array}$ & $\begin{array}{l}1.020 \\
(9.954)\end{array}$ & $\begin{array}{l}-0.358 \\
(0.299)\end{array}$ & $\begin{array}{l}-4.885 \\
(8.944)\end{array}$ \\
\hline Urbanization & $\begin{array}{l}0.165 * * * \\
(0.046)\end{array}$ & $\begin{array}{l}0.174 * * * \\
(0.047)\end{array}$ & $\begin{array}{l}-0.107 \\
(0.219)\end{array}$ & $\begin{array}{l}0.141 * * * \\
(0.042)\end{array}$ & $\begin{array}{l}-0.032 \\
(0.195)\end{array}$ \\
\hline Compulsory Voting & $\begin{array}{l}3.077 * \\
(1.461)\end{array}$ & $\begin{array}{l}2.289 \\
(1.642)\end{array}$ & & $\begin{array}{l}2.370 \\
(1.487)\end{array}$ & \\
\hline Constant & $\begin{array}{l}3.804 \\
(1.461)\end{array}$ & $\begin{array}{l}4.389 \\
(7.904)\end{array}$ & $\begin{array}{l}58.067 \\
(92.05)\end{array}$ & $\begin{array}{l}10.063 \\
(7.394)\end{array}$ & $\begin{array}{l}106.86 \\
(85.98)\end{array}$ \\
\hline$R^{2}$ & 0.849 & 0.861 & 0.901 & 0.871 & 0.911 \\
\hline Elections & 139 & 139 & 139 & 138 & 138 \\
\hline Countries & 29 & 29 & 29 & 29 & 29 \\
\hline Fixed Effects & - & - & $\sqrt{ }$ & - & $\sqrt{ }$ \\
\hline
\end{tabular}

Panel corrected standard errors in parentheses

$* p<0.10, * * p<0.05, * * p<0.01$

Considering that the dataset is a cross-sectionally dominated panel (large $N$ and small $T$ ) and an unbalanced panel (more elections included for some countries), I followed the suggestion of Beck and Katz (1995), who recommend OLS regression with Panel Corrected Standard Errors (PCSE). ${ }^{18}$ I also account for the serial dynamic of the voter turnout models by including a lagged dependent variable, thus making the analysis dynamic (Keele \& Kelly, 2006). For robustness, and to deal

18 The models presented were run using the xtpcse command in Stata 16. 
with the threat of unobservable unit specific error in the composite error term, some models include Fixed Effects estimations. ${ }^{19}$

\section{Results and Analysis}

Table 2 presents the results of OLS with Panel Corrected Standard Errors (PCSE) and Fixed Effects estimations based on the empirical strategy which Arel-Bundock et al. (2021) suggest. Model 1 is based on the conventional strategy including domestic economic variables measured by temporal comparisons (retrospective). The other four models incorporate international benchmark(s)' economy. In model 2 and 3, I use the first spatial reference point (noted Benchmark 1) which appears the most in one's domestic news media on the macroeconomic conditions. Model 4 and 5 are based on the joint spatial reference points (noted Benchmark 2) which is calculated by the weighted average of economic indicators from the three most appeared countries in domestic news messages. PCSE estimations are in Model 2 and 4, and Fixed Effects estimations are in Model 3 and $5 .^{20}$

The first noticeable point is that the domestic economy appears to have no effect as shown in Model 1. The coefficients of both Domestic GDP and Domestic Unemployment are statistically insignificant. Two interpretations can be made on this null finding. First, the null finding is consistent with Blais' (2006) conclusion in that the economy has no impact on turnout. Perhaps at the macro-level tests we can only observe the total effects of two expectations (withdrawal and mobilization), which cancel each other as it does not distinguish between the two mechanisms (Radcliff, 1992).

Second, the ambiguity may come in part from poor measures of the economic variable. Argued in the preceding section, the retrospective economy variable is insufficient in its ability to assist citizens in evaluating the health of the economy. If citizens receive more accurate and useful information on incumbent competence at handling the economy by 'comparing' their performance with others, the same way that individuals tend to 'compare' things in their daily lives, empirical tests using the retrospective economy variable will yield biased estimations.

To turn our attention to the central argument of the paper, we need to focus on Benchmark variable (noted as $\beta_{2}$ in Table 1). According to Arel-Bundock et al.'s specification (2021), this indicates the marginal effect of the benchmark economy holding the domestic economy constant, so represents the scenario that the domestic economy underperforms the benchmark(s)'. As shown in Table 2, the coefficient of Benchmark GDP is statistically significant, and its effect is robust

\footnotetext{
19 The Fixed Effects specification does not include variables that do not (or rarely) vary overtime within a country such as Compulsory Voting.

${ }^{20}$ For robustness, I also estimate the same models using Prais-Winsten regression models with heteroskedastic Panel Corrected Standard Errors. The results, which are available in Table A2 in Online appendix, remain robust. Furthermore, I tested how sensitive my main result is to the in- or exclusion of control variables, and find that the results for the main benchmark variables did not change.
} 


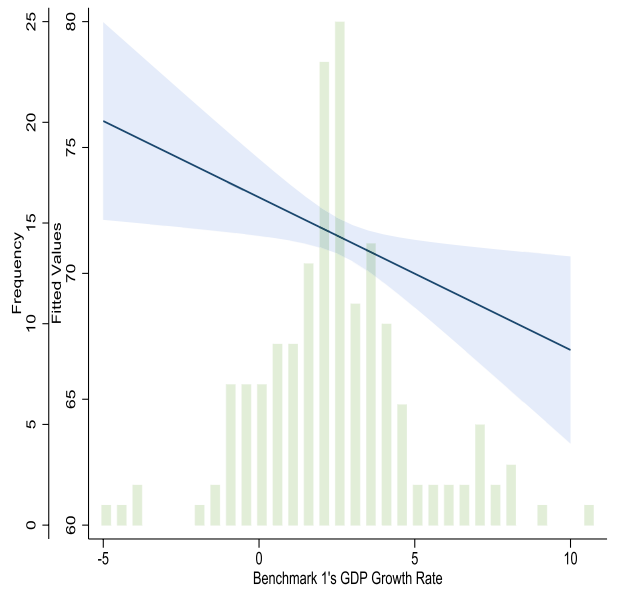

(a) Benchmark 1

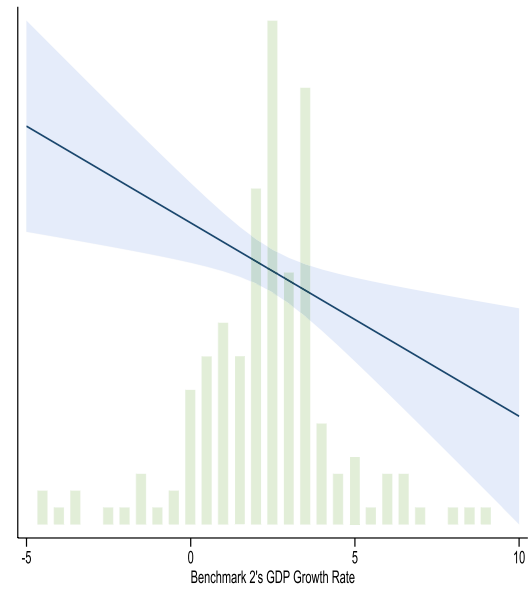

(b) Benchmark 2

Fig. 3 Predictive Margins of Benchmark(s) Economy on Turnout (CI 95\%). The figure is based on the PCSE estimations (Model 2 and Model 4) in Table 2.

across two sets of estimation strategies and two sets of benchmark. The sign is negative, meaning that a poor relative growth compared to the benchmark(s)' reduces the level of turnout.

The finding is in line with Hypothesis 1a (H1a), and thus of course would be seen as falsifying Hypothesis $2 \mathrm{a}(\mathrm{H} 2 \mathrm{a})$, which predicts the opposite in that turnout will increase with a poor relative growth. However, from the macro-level analysis such as this, my data and models cannot directly test the effect of immediate factors in the 'funnel of causality' such as individuals' confidence or grievance on their decision to turn out or not. Thus, my finding increases the assessment of the probability that the effect of withdrawal (H1a) is stronger than the effect of mobilization (H2a) with a poor relative growth rate. Simply put, in the absence of a mobilization effect, the withdrawal effect might have even larger consequences on voter turnout.

Figure 3 presents the substantive impact of benchmark(s)' growth rates, which plots the average predictive marginal effects on turnout at varying levels of benchmark(s) growth rate from the two PCSE models in Table 2. Sub-figure (a) is based on a single benchmark (Benchmark 1), and sub-figure (b) is based on joint benchmarks (Benchmark 2). The outer y-axis and the bar graph show the distribution of Benchmark variables. The inner y-axis and solid line indicate the linear predicted values of turnout (\%). The shaded area shows the $95 \%$ confidence intervals. The figure clearly indicates that when benchmark(s) GDP growth increases, holding domestic growth rate constant (meaning that domestic growth becomes underperforming compared to the reference point(s)), turnout level also decreases. The predicted value of turnout is above $75 \%$ at the lowest value of GDP growth rate of Benchmark(s), however the predicted value of turnout reaches around $67 \%$ with Benchmark 1 and 64\% with Benchmark 2 where the GDP growth rate of Benchmark(s) arrives at their maximum value. 


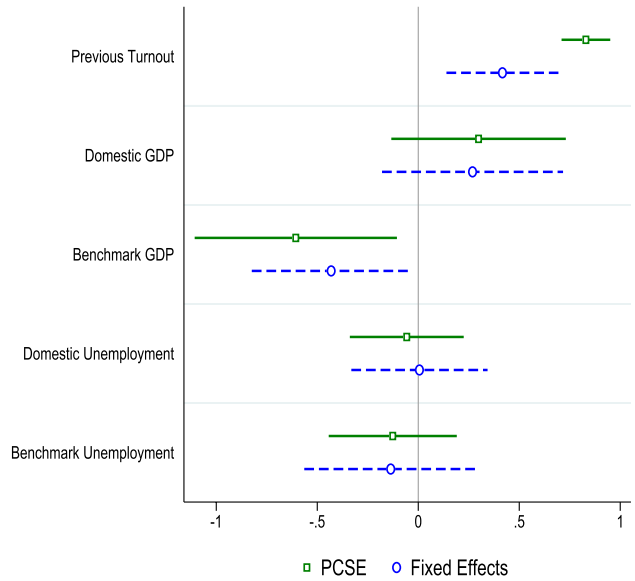

(a) Benchmark 1

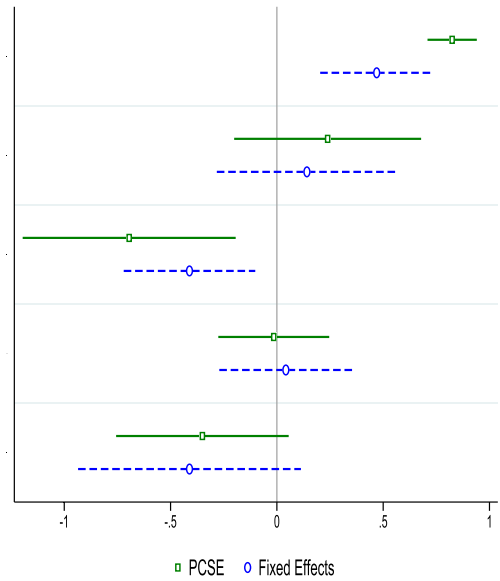

(b) Benchmark 2

Fig. 4 Effect of domestic and benchmark(s) economy on turnout (CI 95\%). For simplicity, the figure shows the key variables only although it is based on the full models in Table 2.

Returning to Table 2, the Domestic variable (noted as $\beta_{1}$ in Table 1) shows the marginal effect of domestic economy holding benchmark(s)' economy constant, suggesting out-performing economic conditions. It is expected that a good relative economy increases turnout $(\mathrm{H} 1 \mathrm{~b})$ with strong confidence in politics, or decreases turnout $(\mathrm{H} 2 \mathrm{~b})$ as the electoral stakes diminish since the strong relative economy helps incumbents win the election. The positive sign of Domestic GDP is in line with former (H1b), but its statistical significance does not reach at the conventional level across all models. Thus, with respect to out-performing growth rate, neither $\mathrm{H} 1 \mathrm{~b}$ nor $\mathrm{H} 2 \mathrm{~b}$ is supported.

Figure 4, which plots each of the coefficients, further highlights the difference in the effects between under-performance and out-performance. The solid line represents the confidence intervals of the coefficients from PCSE estimations, and the dashed line represents the confidence intervals of the coefficients from Fixed Effect estimations in Table 2. The negative effect of the under-performing growth rates on turnout is apparent since the coefficient plots of Benchmark GDP (or $\beta_{2}$ ) are blow zero, and the effects are robust in four models containing no zero line in their confidence intervals. Conversely, the coefficient plots of Domestic GDP (or $\beta_{1}$ ) suggest that out-performing growth rates have no impact on turnout.

This simple comparison might imply an observable implication in that voters react asymmetrically to the economic condition: They tend to react strongly to under-performing conditions, but their responses to over-performing conditions are not so much. This finding speaks to literature on 'negativity bias' in political behavior (Lau, 1982; Soroka, 2006). In particular, Lau (1982) notes that there is a tendency for "negative information to have more weight than equally extreme or equally likely positive information." (353) Much scholarship has empirically shown that there is a clear negativity bias in media as it gives much more coverage to 
negative economic news than positive (Soroka, 2006; Hetherington, 1996). Being exposed to this one-sided media, citizens appear to react asymmetrically to the economy itself. My finding shows evidence that voters are more sensitive toward relatively poor conditions, whereas their reactions toward relatively good conditions remain uncertain.

Turning our attention to the relative performance on unemployment, the coefficients of Domestic Unemployment and Benchmark Unemployment are never distinguishable from zero in all four models in Table 2 and Fig. 4, suggesting that there is no evidence of either withdrawal or mobilization hypothesis. This is the similar finding in that the benchmark unemployment has no effect in vote choice models (Kayser \& Peress, 2012; Aytaç, 2018; Park, 2019).

\section{Discussion}

This paper has employed the concept of relative economy in order to provide an explanation for aggregate-level variation in voter turnout. Voter evaluations of a politician or political party's skill at handling economy have been shown to be based on more than merely national economic conditions. Instead, voters tend to look to other countries' economies to gauge the relative conditions of their economy. The relative economy provides voters with a competence signal indicating how well the incumbent is handling the economy. Existing literature suggests that a relatively poor economy either leads voters to become inactive in elections due to their decreased confidence in government and alienation from and indifference to politics, or instead galvanizes voters to participate in elections in order to express their grievances actively and hold their government accountable at the polls. Similarly, an economy which out-performs relative to others is expected to either increase voter turnout because of the strong confidence in politics that it brings, or otherwise decrease turnout because the electoral stakes are lowered.

This paper's finding indicates that voter turnout in a country decreases when that country's economic growth rate underperforms compared to its reference country or group of countries. This is in line with the idea that poor economic performance leads voters to abstain from voting by lowering citizens' confidence in their government. Conversely, an economy that outperforms its benchmarks appears to have no impact on turnout. This implies that perhaps there is an asymmetry in voters' reactions to the relative economy. Voters are far more sensitive to relatively poor economic growth than to relatively strong economic growth, which suggests a negativity bias in voting behavior. In sum, through the use of better measures of economic information, this research provides strong evidence supporting the withdrawal hypothesis.

The main contribution of this paper is that it is the first study (to the best of the author's knowledge) that employs 'spatially' benchmarked economy variables in turnout models. Although existing literature implicitly assumes that resourcebased and competence-based economic mechanisms affect voter turnout, testing of the latter mechanism has been limited because of the sole reliance on 'retrospective' economic information. Resulting explanations of voter assessment 
of government are therefore incomplete and limited. Consider a situation where one's own domestic economy is poorer than the previous year but currently performing better than other countries' economies. In this case, which competence signal, weak or strong, would voters capture?

If voters tend to use spatially benchmarked values for economic evaluations, using temporally benchmarked variables in a turnout model would lead to attenuation bias. Therefore, on average, the estimated Ordinary Least Square (OLS) effect will be always closer to zero than it is supposed to be (Wooldridge, 2015). Perhaps this could explain the 'null' finding from most cross-national studies about the relationship between economic fluctuation and voter turnout. Since a temporally benchmarked economy variable can fail to help voters extract the competency signal and lacks validity in measuring what it is purported to measure, introducing spatially benchmarked economy variables into the turnout model has substantial potential benefit for empirical accuracy.

If spatial comparison is important, using appropriate reference point(s) is also crucial for conducting an accurate empirical test. Including an inappropriate or irrelevant reference point such as a universal benchmark would result in model misspecification, and consequently induce omitted variable bias. Thus, this paper has attempted to construct the best possible relative economy variables (a novel contribution to existing literature) by using media-guided spatial reference points per country and per election based on domestic news media.

The third contribution is that this research expands the scope of the benchmarking hypothesis. Although the relative performance theory has been around for a long time, its applications have been very limited. This research attempts to expand the boundary of applications by looking at how voters react to relative economic performance when they make a decision to turn out. The finding of this research demonstrates the applicability of the benchmarking hypothesis to various research topics in political science.

Although the weight of evidence points toward a negative relationship between a poor relative economy and turnout at the aggregate level, future research will be needed to pursue the issue that has been raised here. At macro-level tests, the relative economy variable has been understood as a contextual factor, which is a distant cause to explain the levels of turnout. However, a part of the underlying mechanisms of this paper relies more or less on micro-level understanding, with issues related to the potential ecological fallacy, in that the relative economy either mobilizes or dampens motivations of 'voters', not of 'countries'. Each chain of logic, from the economic conditions to the levels of trust, satisfaction, and electoral stake, and from those factors to turnout, is carefully guided by existing literature; however, it would be useful to test how distant economy factors (contextual characteristics) influence immediate factors (individual characteristics) at micro-level analyses. For instance, one interesting question is how a relative economy affects political trust, democratic satisfaction, and political efficacy. As discussed earlier, existing literature informs much about the role of the domestic economy on these psychological factors, but we are less informed about how relative economic performance affects the characteristics of voters and 
their motivation to turn out. Thus, further investigations based on individual-level analyses would validate the 'causal distance' that this research employs.

Another extension to this research would examine the role of the media signal directly by measuring the 'tone' of the economic news reports. This paper assumes that citizens benchmark domestic economic performance with the assistance of the media, which disseminates information about the overall variances in shocks to their national economy compared to foreign economies. In this regard, it would be useful to directly model the tone of the economic news to see how economic information received by citizens is framed by media outlets. For instance, what factors influence how the media benchmarks? Do political parties and candidates make of an effort to take advantage of the way the media benchmarks? Under what conditions does the benchmarking become more salient? These questions, beyond the scope of current analysis, could promise fruitful ground for future research.

Finally, this paper suggests that variation in turnout is likely to have important electoral implications. In particular, given the 'frozenness' of party systems (Lipset \& Rokkan, 1967), the impact of party mobilization in determining election outcomes is eroding (Van der Brug, 2010), especially for countries that do not experience significant party system changes between elections. The waning impact of party mobilization means that elections are often determined by differential turnout, and the electoral effects of turnout have therefore increased (Hansford \& Gomes, 2010). For instance, a decision to turn out for a collective vote against the incumbent, perhaps as punishment for a troubled economy or an unpopular policy, will have a substantive effect on the incumbent's re-election chances. The paper speaks to this expectation in that a poor relative economy may help the government by demobilizing the collective vote against the incumbent. This is good news for the unpopular incumbent, but bad news for democratic theorists since it weakens the accountability mechanism. That being said, those who lose confidence in their incumbent and would otherwise support the opposition are less likely to turn out (Radcliff, 1992), and thus the expected punishment is less delivered.

Supplementary Information The online version contains supplementary material available at https://doi. org/10.1007/s11109-021-09736-4.

Acknowledgements The author gratefully acknowledges helpful comment, suggestion, and advice from Benjamin Radcliff and three anonymous reviewers. The author would also like to thank Michael S. Lewis-Beck, Mary Stegmaier, Laron Williams, Dan Bowen, Ruth Dassonneville, Gangsoo Jun, Kristian Wingo, and Aaron Kushner for their invaluable help and comments.

Data Availability The replication materials (both Data and Code) are available on the Mendeley Data repository under: "How does a Relative Economy Affect Voter Turnout?" (POBE-D-19-00329) at https:// data.mendeley.com/datasets/hvhwm2tybf/1.

Open Access This article is licensed under a Creative Commons Attribution 4.0 International License, which permits use, sharing, adaptation, distribution and reproduction in any medium or format, as long as you give appropriate credit to the original author(s) and the source, provide a link to the Creative Commons licence, and indicate if changes were made. The images or other third party material in this article are included in the article's Creative Commons licence, unless indicated otherwise in a credit line to the material. If material is not included in the article's Creative Commons licence and your intended use is not permitted by statutory regulation or exceeds the permitted use, you will need to obtain permission 
directly from the copyright holder. To view a copy of this licence, visit http://creativecommons.org/licen ses/by/4.0/.

\section{References}

Arcelus, F., \& Meltzer, A. H. (1975). The effect of aggregate economic variables on congressional elections. American Political Science Review, 69(4), 1232-1239.

Arel-Bundock, V., Blais, A., \& Dassonneville, R. (2021). Do Voters Benchmark Economic Performance? British Journal of Political Science, 51, 437-449.

Armingeon, K., Isler, C., Knopfel, L., Weisstanner, D., \& Engler, S. (2016). Codebook: Comparative political data set 1960-2014.

Aytaç, S. E. (2018). Relative economic performance and the incumbent vote: a reference point theory. The Journal of Politics, 80(1), 16-29.

Beck, N., \& Katz, J. N. (1995). What to do (and not to do) with time-series cross-section data. American Political Science Review, 89(3), 634-647.

Benton, A. L. (2005). Dissatisfied democrats or retrospective voters? Economic hardship, political institutions, and voting behavior in Latin America. Comparative Political Studies, 38(4), 417-442.

Blais, A. (2006). What affects voter turnout? Annu. Rev. Polit. Sci., 9, 111-125.

Blais, A., \& Dobrzynska, A. (1998). Turnout in electoral democracies. European Journal of Political Research, 33(2), 239-261.

Blais, A., Nadeau, R., Gidengil, E., \& Nevitte, N. (2001). Measuring strategic voting in multiparty plurality elections. Electoral Studies, 20(3), 343-352.

Blais, A. (2000). To vote or not to vote?: The merits and limits of rational choice theory. University of Pittsburgh Pre.

Bormann, N.-C., \& Golder, M. (2013). Democratic electoral systems around the world, 1946-2011. Electoral Studies, 32(2), 360-369.

Cox, G. W. (1988). Closeness and turnout: A methodological note. The Journal of Politics, 50(3), $768-775$.

Cox, M. (2003). When trust matters: Explaining differences in voter turnout. J. Common Mkt. Stud., 41, 757.

Dassonneville, R., \& Lewis-Beck, M. S. (2019). A changing economic vote in Western Europe? Longterm vs. short-term forces. European Political Science Review, 11(1), 91-108.

Dettrey, B. J., \& Schwindt-Bayer, L. A. (2009). Voter turnout in presidential democracies. Comparative Political Studies, 42(10), 1317-1338.

Duch, R. M., \& Stevenson, R. T. (2008). The economic vote: How political and economic institutions condition election results. Cambridge University Press.

Döring, H. \& Manow, P. (2012). Parliament and government composition database (ParlGov). An infrastructure for empirical information on parties, elections and governments in modern democracies. Version, 12(10).

Van Erkel, P. A., \& Der Meer, T. W. G. (2016). Macroeconomic performance, political trust and the Great Recession: A multilevel analysis of the effects of within-country fluctuations in macroeconomic performance on political trust in 15 EU countries, 1999-2011. European Journal of Political Research, 55(1), 177-197.

Fauvelle-Aymar, C., \& Stegmaier, M. (2008). Economic and political effects on European Parliamentary electoral turnout in post-communist Europe. Electoral Studies, 27(4), 661-672.

Fornos, C. A., Power, T. J., \& Garand, J. C. (2004). Explaining voter turnout in Latin America, 1980 to 2000. Comparative Political Studies, 37(8), 909-940.

Franklin, M. N. (2004). Voter turnout and the dynamics of electoral competition in established democracies since 1945. Cambridge University Press.

Geys, B. (2006). Explaining voter turnout: A review of aggregate-level research. Electoral Studies, 25(4), $637-663$.

Gray, M., \& Caul, M. (2000). Declining voter turnout in advanced industrial democracies, 1950 to 1997: The effects of declining group mobilization. Comparative Political Studies, 33(9), 1091-1122.

Grönlund, K., \& Setälä, M. (2007). Political trust, satisfaction and voter turnout. Comparative European Politics, 5(4), 400-422. 
Gurr, T. R. (1970). Why men rebel. London: Routledge.

Hansen, T. (1994). Local elections and local government performance. Scandinavian Political Studies, $17(1), 1-30$.

Hansford, T. G., \& Gomez, B. T. (2010). Estimating the electoral effects of voter turnout. American Political Science Review, 104(2), 268-288.

Hetherington, M. J. (1996). The media's role in forming voters' national economic evaluations in 1992. American Journal of Political Science, 40(2), 372.

Hooghe, M., Marien, S., \& Pauwels, T. (2011). Where do distrusting voters turn if there is no viable exit or voice option? The impact of political trust on electoral behaviour in the Belgian regional elections of June 2009. Government and Opposition, 46(2), 245-273.

Karp, J. A., \& Banducci, S. A. (2008). When politics is not just a man's game: Women's representation and political engagement. Electoral Studies, 27(1), 105-115.

Karp, J. A., \& Milazzo, C. (2015). Democratic scepticism and political participation in Europe. Journal of Elections, Public Opinion and Parties, 25(1), 97-110.

Kayser, M. A., \& Peress, M. (2012). Benchmarking across borders: electoral accountability and the necessity of comparison. American Political Science Review, 106(3), 661-684.

Keele, L., \& Kelly, N. J. (2006). Dynamic models for dynamic theories: The ins and outs of lagged dependent variables. Political Analysis, 14(2), 186-205.

Kern, A., Marien, S., \& Hooghe, M. (2015). Economic crisis and levels of political participation in Europe (2002-2010): The role of resources and grievances. West European Politics, 38(3), 465-490.

Klandermans, B., Van der Toorn, J., \& Van Stekelenburg, J. (2008). Embeddedness and identity: How immigrants turn grievances into action. American Sociological Review, 73(6), 992-1012.

Klandermans, B., Roefs, M., \& Olivier, J. (2001). Grievance formation in a country in transition: South Africa, 1994-1998. Social Psychology Quarterly, 41-54.

Kriesi, H. (2012). The political consequences of the financial and economic crisis in Europe: Electoral punishment and popular protest. Swiss Political Science Review, 18(4), 518-522.

Lau, R. R. (1982). Negativity in political perception. Political Behavior, 4(4), 353-377.

Lipset, S. M. (1960). Party systems and the representation of social groups. European Journal of Sociology/Archives Européennes de Sociologie/Europäisches Archiv für Soziologie, 1(1), 50-85.

Lipset, S. M., \& Rokkan, S. (1967). Party systems and voter alignments: Cross-national perspectives, vol. 7. Free press.

Van der Meer, T. W. G. (2018). Economic performance and political trust. In Oxford handbook of social and political trust, ed. Eric M. Uslaner. Oxford University Press chapter, 25, 599-616.

Pacek, A. C., Pop-Eleches, G., \& Tucker, J. A. (2009). Disenchanted or discerning: Voter turnout in postcommunist countries. The Journal of Politics, 71(2), 473-491.

Palmer, H. D., \& Whitten, G. D. (1999). The electoral impact of unexpected inflation and economic growth. British Journal of Political Science, 29(4), 623-639.

Park, B. B. (2019). Compared to what? Media-guided reference points and relative economic voting. Electoral Studies, 62.

Pischke, S. (2007). Lecture notes on measurement error. London: London School of Economics.

Powell, G. B. (1986). American voter turnout in comparative perspective. American Political Science Review, 80(1), 17-43.

Quaranta, M., \& Martini, S. (2016). Does the economy really matter for satisfaction with democracy? Longitudinal and cross-country evidence from the European Union. Electoral Studies, 42, 164-174.

Radcliff, B. (1992). The welfare state, turnout, and the economy: A comparative analysis. American Political Science Review, 86(2), 444-454.

Riker, W. H., \& Ordeshook, P. C. (1968). A Theory of the Calculus of Voting. American Political Science Review, 62(1), 25-42.

Rosenstone, S. J. (1982). Economic adversity and voter turnout. American Journal of Political Science, $25-46$.

Schlozman, K. K., \& Verba, S. (1979). Injury to insult: Unemployment, class, and political response. Harvard University Press.

Smets, K., \& Van Ham, C. (2013). The embarrassment of riches? A meta-analysis of individual-level research on voter turnout. Electoral Studies, 32(2), 344-359.

Soroka, S. N. (2006). Good news and bad news: Asymmetric responses to economic information. The Journal of Politics, 68(2), 372-385.

Southwell, P. L. (1988). The mobilization hypothesis and voter turnout in Congressional elections, 19741982. Western Political Quarterly, 41(2), 273-287. 
Stegmaier, M., Lewis-Beck, M. S., \& Park, B. B. (2017). The VP-Fuction: A Review. In J. Evans, K. Arzheimer, \& M. Lewis-Beck (Eds.), The Sage Handbook of Electoral Behaviour. Sage chapter 25.

Taylor, M. A. (2000). Channeling frustrations: Institutions, economic fluctuations, and political behavior. European Journal of Political Research, 38(1), 95-134.

Tillman, E. R. (2008). Economic judgments, party choice, and voter abstention in cross-national perspective. Comparative Political Studies, 41(9), 1290-1309.

Van der Brug, W. (2010). Structural and ideological voting in age cohorts. West European Politics, 33(3), 586-607.

Wass, H. M., \& Blais, A. (2017). Turnout. In SAGE Handbook of Electoral Behaviour, ed. J. Evans Arzheimer. K. and M. Lewis-Beck. Sage chapter, 20, 459-487.

Weschle, S. (2014). Two types of economic voting: How economic conditions jointly affect vote choice and turnout. Electoral Studies, 34, 39-53.

Wilkin, S., Haller, B., \& Norpoth, H. (1997). From Argentina to Zambia: a world-wide test of economic voting. Electoral Studies, 16(3), 301-316.

Wooldridge, J. M. (2015). Introductory econometrics: A modern approach. Nelson Education.

Yockey, M. D., \& Kruml, S. M. (2009). Everything is relative, but relative to what? Defining and identifying reference points. Journal of Business and Management, 15(1), 95.

Publisher's Note Springer Nature remains neutral with regard to jurisdictional claims in published maps and institutional affiliations. 